\title{
LOCAL PRODUCTIVITY The real differences across UK cities and regions
}

Christina Beatty

Steve Fothergill

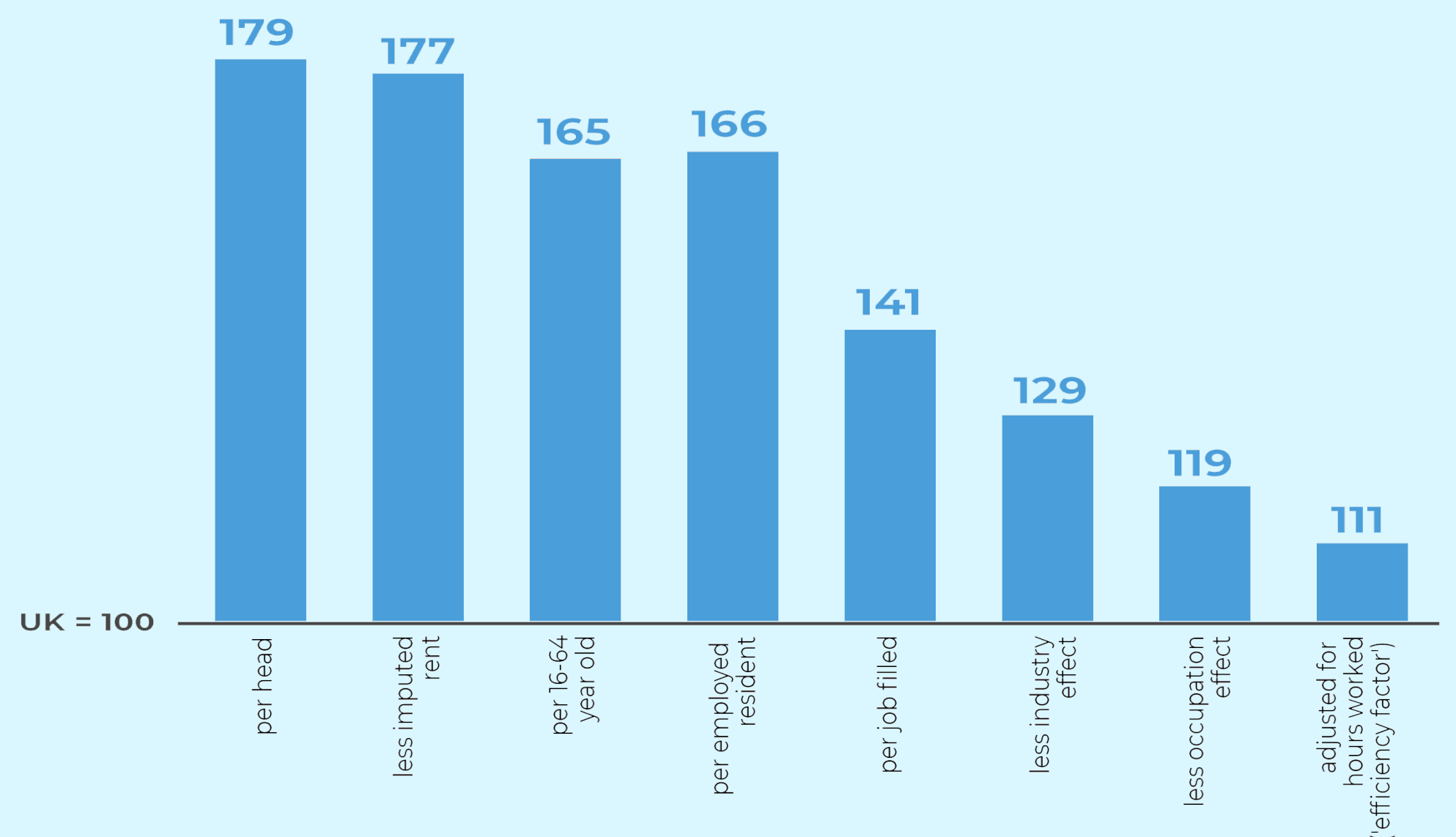





\section{LOCAL PRODUCTIVITY \\ The real differences across UK cities and regions}

Christina Beatty and Steve Fothergill

Centre for Regional Economic and Social Research

Sheffield Hallam University

July 2019 


\section{Summary}

This paper disaggregates productivity across UK cities and sub-regions. Beginning with the wide variations in output (GVA) per head, it presents a series of alternative measure of productivity culminating in a new measure of the efficiency with which goods and services are produced in different parts of the country. In doing so it adjusts for a range of factors including employment rates, commuting, industrial mix and occupational structure.

- Despite a GVA per head far in excess of the UK average, London emerges as little more efficient than the rest of the country

- The main regional cities, which as a group also have GVA per head above the UK average, slip below average on the estimates of efficiency

- Less prosperous parts of the UK, with low GVA per head, generally catch up with the national average on estimated efficiency

- Overall, the differences in efficiency across the UK appear modest

The evidence represents a serious challenge to agglomeration economics and suggests that the promotion of growth and jobs in less prosperous parts of the country is not damaging to the productivity of the UK economy as a whole.

\section{Acknowledgements}

This research was financed by Sheffield Hallam University's Creating Knowledge Investment Programme (CKIP). The authors would like to thank Peter Wells for his enthusiastic support for this research and David Leather for his assistance in producing the graphics. 


\section{LOCAL PRODUCTIVITY}

The real differences across UK cities and regions

\section{Introduction}

'Productivity' has become central to contemporary debate on the performance of the UK economy. Over the course of the recovery from the financial crisis a decade ago, output has grown steadily if unspectacularly but labour productivity has remained almost stagnant. As a result, economic growth has resulted almost entirely from an increase in employment.

'Productivity' has also become central to debates around regional and local differences in prosperity. Whereas for many years the disparities in economic well-being across the UK would primarily have been described in terms of unemployment, increasingly it is the gaps in productivity that attract attention. It is now common to contrast the high output per head in London, for example, with the much lower levels found in parts of the North or in places such as Cornwall and West Wales \& the Valleys.

But what exactly is 'productivity', and how should it be defined and measured at the local scale? At one end of the spectrum, GVA 1 per head and its close relative GDP $^{2}$ per head are well established measures of output. In the case of GDP per head, this has long been used to allocate EU regional aid to the UK and other parts of Europe. GVA and GDP per head both measure the value of production in an area in relation to its population. At the other end of the spectrum, there is productivity defined in terms of the efficiency with which any given productive task is undertaken. Efficiency is not about how much is produced but rather about how well it is produced.

Just because an area has a low GVA or GDP per head does not necessarily mean that its workforce is any less efficient than elsewhere. It could be, for example, that the area has a concentration of industries or occupations that are associated with lower output wherever they are located, or that there is a net flow of commuters to neighbouring areas so their production is recorded where they work rather than where they live. Between GVA or GDP per head and efficiency a number of important measurement issues come into play.

\footnotetext{
${ }^{1}$ Gross Value Added. The value of goods and services produced less intermediate inputs.

${ }^{2}$ Gross Domestic Product. The market value (including taxes and subsidies) of the final goods and services produced.
} 
Most economists and economic geographers understand this complexity without necessarily being able to readily quantify its effects. But in less well-informed discussion it is not uncommon for the distinction between 'production' and 'efficiency' to become blurred. At worst, the big differences in GVA or GDP per head across the UK can quite misleadingly be interpreted as indicating that workers in some parts of the country are two or even three times more productive, more efficient or even harder working.

That there are big differences in the efficiency with which productive tasks are undertaken in different parts of the UK seems inherently unlikely. The UK is a relatively small country with education and training that does not vary widely from place to place and with plentiful flows of knowledge and technology. By and large, a supermarket, a school or a hospital, for example, will tend to be organised along much the same lines wherever it is located so it is hard to see how big differences in labour productivity might arise in these sectors or many others.

There are likely to be local clusters within manufacturing and within some services that do benefit from local advantages in terms of skills, knowledge or specialised suppliers, resulting in higher productivity in those places. It is worth remembering, however, that manufacturing now employs less than 10 per cent of the UK workforce so by itself seems unlikely to generate the big regional and local differences in output per head that can be observed. Within manufacturing there are also strong competitive pressures on firms to stay reasonably close to best-practice technology and organisation, the alternative being commercial failure.

In this paper we disaggregate the differences in productivity across the UK into their component parts. Our starting point is the big variation in GVA per head and, after a number of intermediate steps, we arrive at a measure of local 'efficiency'. At each stage the comparison we make is with the national average so the local figures we present are all expressed as an index number where the UK $=100$. We undertake this exercise at two geographical scales:

- For all UK sub-regions - Local Enterprise Partnership (LEP) areas in England, NUTS 2 areas in Scotland and Wales

- For each of the main regional cities in Great Britain

The conclusions have important implications for the way regional and local differences across the UK are understood. 


\section{Definitions and methods}

\section{Gross Value Added (GVA) per head}

Our starting point is GVA per head - a standard statistical measure published regularly by the Office for National Statistics (ONS). We use the most up-to-date figures available at the time of writing, for $2017^{3}$. GVA per head (that is, per resident) varies from 179 per cent of the UK average in London to just 65 per cent in Cornwall, 63 per cent in West Wales \& the Valleys and 61 per cent in the newly-defined Southern Scotland NUTS 2 region. GVA per head should not really be confused with 'productivity' but it is a legitimate and useful measure of the value of economic activity that takes place in an area in relation to its resident population.

\section{GVA per head less imputed rent}

'Imputed rent' is an odd concept, measuring the value of housing services accruing to owner-occupiers - in effect, the rent they would have had to pay if they had not owned their property. Imputed rent is conventionally included in GVA and GDP statistics because it would be lop-sided to include only the housing services for which rent is paid, especially in international comparisons because different countries have different housing tenures. Housing tenure and costs also vary across the UK so the amount added into GVA and GDP statistics varies from place to place. Its exclusion from the figures here makes sense, however, in order to provide a measure of output more closely related to the input of labour. Figures on imputed rent, by sub-region and by city, are published by $\mathrm{ONS}^{4}$. Excluding imputed rent lowers GVA per head, relative to the UK average, in the parts of southern England where housing costs are high and a large proportion of the housing stock is owneroccupied.

\section{GVA per 16-64 year old}

This expresses GVA (excluding imputed rent) in relation to the resident working age ${ }^{5}$ population rather than in relation to the population as a whole. This is relevant because different parts of the UK have different proportions of the population above and below working age and, because most under-16 and most-over 65 don't participate in the labour market, it makes sense to look at production in relation to the working age population. An above average proportion of over-65s in some rural and coastal areas deflates measures of GVA per head based on the population as a whole. Conversely, London's low proportion of over-65s boosts its GVA figure. Looking at GVA in relation to the working age population adjusts for this distortion.

\footnotetext{
${ }^{3}$ The figures are for what ONS calls 'balanced GVA', which combines income and production measures.

${ }^{4}$ Office for National Statistics (2019) Regional and sub-regional productivity in the UK: February 2019.

${ }^{5}$ Source: ONS
} 
Not all working-age residents are in work of course, and some over-65s do remain in employment. Expressing GVA (excluding imputed rent) in relation to the employed resident population takes account of the differences in employment rates across the country. In practice the main working-age groups not engaged in paid employment are students (especially in university towns and cities), men and women out of the labour market on disability benefits (especially in some older industrial areas and seaside towns) and women at home with children (in most areas). The unemployed are these days a smaller group. Estimates of the employed resident population in each area come from the UK's Annual Population Survey ${ }^{6}$.

\section{GVA per filled job}

GVA per filled job is one of two ONS measures of local productivity (the other is GVA per hour worked) and the figures here are taken directly from $\mathrm{ONS}^{7}$. The jobs are those located in the area and include the employed, self-employed, government-supported trainees and members of the armed forces. This measure adjusts for commuting because the number of jobs in each area is not necessarily the same as the number of residents in work. This is especially important in London and in the main regional cities where there are large net inflows of commuters. In the cities, GVA per head is inflated because it counts the all the production but not all the workers. Conversely, in the commuting hinterland of the cities GVA per head is lowered by the omission of commuters' production. GVA per filled job also adjusts for double-jobbing (when some individuals hold two or more jobs).

There are nevertheless important shortcomings in GVA per filled job as a measure of productivity. Although it documents the value of production in relation to the number of jobs it does not say anything about the efficiency with which production takes place. A high GVA per filled job does not necessarily mean that the workers in that location are any more productive or efficient than workers doing the same tasks in other locations. To comment on 'efficiency' it is necessary to adjust for the mix of industries, the mix of occupations and hours worked.

\section{Adjustment for industry mix}

Different industries have different levels of output per head, and the mix of industries varies from place to place. Across the UK as a whole, GVA per employee in banking, finance and business services, for example, is two and a half times higher than in retailing, distribution, hotels and restaurants ${ }^{8}$. We therefore calculate what would have been each area's GVA per job if each industry in the area had the UK average GVA per job for that industry. Economic

\footnotetext{
${ }^{6}$ To help offset sampling errors in the APS, the figures used here are an average of the data for 2016 , 2017 and 2018.

${ }^{7}$ Office for National Statistics (2019) op.cit.

${ }^{8}$ ONS data for 2017
} 
geographers will recognise this as a 'shift-share analysis', a well-tried and proven technique. Here we disaggregate all workplace employment into eight different industries ${ }^{9}$. We then deduct the industry effect from the GVA per filled job.

\section{Adjustment for occupational mix}

Within each industry there are also spatial divisions of labour: managers and professionals tend to be located in some places, notably London, whereas the workers undertaking routine production or delivering routine services are more prevalent elsewhere. This boosts GVA per job in the places where managers and professionals are located (because their higher pay is counted as higher output) and lowers the figures where they are a lower proportion of the workforce. To adjust for this effect we undertake a second shift-share analysis, disaggregating the workplace employment in each area in each industry into nine occupational groups ${ }^{10}$. As a proxy for GVA per person in each occupation we use UK average gross hourly earnings of employees in each occupational group ${ }^{11}$. The impact of occupational mix is the difference between the impact of industry mix (as measured above) and the expected GVA per job in each area calculated via this second shift-share exercise.

\section{Adjusted for hours worked (the 'efficiency factor')}

The final adjustment is for differences between places in hours worked. The proportion of part-time jobs in London in particular is lower than the national average, boosting London's GVA per job compared to other areas. The Office for National Statistics publishes figures on average hours worked in each area, allowing the necessary adjustment.

The resulting figure is what we have termed the 'efficiency factor' - the productivity of workers in each area after having adjusted for the mix of industries, the mix of occupations and hours worked. Unlike GVA per filled job, which simply counts the value of production per worker, the 'efficiency factor' tries to measure how well, compared to the national average, the production of goods and services is carried out in each location.

\footnotetext{
${ }^{9}$ SIC sections A, B, D \& E (Agriculture, Mining, Electricity, Gas, Water and Waste), C (Manufacturing), $F$ (Construction), G \& I (Retail, Distribution, Hotels and Restaurants), H \& J (Transport and Communications), $K, L, M, \& N$ (Banking, Finance and Business services), $O, P \& Q$ (Public administration, Education and Health), R, S \& T (Other services). Sources: Workplace employment by area, 2011 Census of Population; GVA per employee by industry 2017, ONS. Data on workplace employment by industry for later years is either subject to sampling error (APS) or omits large numbers of self-employed (Business Register and Employment Survey) and is therefore unsuitable for this exercise.

${ }^{10}$ (1) Managers, directors and senior officials, (2) Professional occupations, (3) Associate professional and technical occupations, (4) Administrative and secretarial occupations, (5) Skilled trades occupations, (6) Caring, leisure and other service occupations, (7) Sales and customer service occupations, (8) Process, plant and machine operatives, (9) Elementary occupations. Source: Workplace employment by area, 2011 Census of Population (Resident employment by area for Scotland owing to data availability).

${ }^{11}$ Source: Labour Force Survey
} 
The 'efficiency factor' for each area nevertheless comes with a health warning: these are estimates based on the cumulative effect of a number of calculations and inevitably subject to a margin of error. In particular, it is unlikely that the adjustments for industry and occupation will have been able to take full account of each of these factors. Within managerial and professional occupations, for example, the very highest paid jobs are often located in London and the simple nine-fold classification of occupations used here is unable to take this into account.

\section{The disaggregation of local productivity}

The results of applying these methods to UK sub-regions and to the main regional cities are presented in full in the appendix. Each productivity indicator in these tables expresses GVA in each area as an index of the UK average, beginning with GVA per head and progressing in steps to the 'efficiency factor'. It is easiest to understand the findings by looking at two contrasting examples: London and West Wales \& the Valleys.

\section{Example: London}

London is especially interesting because it is an extreme case. With a GVA per head of 179 per cent of the UK average it is far ahead of the next most productive sub-region (Thames Valley Berkshire at 153 per cent). Figure 1 disaggregates this very high GDP per head:

- Excluding imputed rent brings down London's figure but only to 177 per cent of the UK average

- Re-basing on the working age population brings down London's figure rather more, to 165 per cent, because the over-65s are a smaller group in London than elsewhere

- GVA per employed resident makes little further difference, mainly because London's large student population keeps its employment rate fairly close to average

- GVA per filled job makes a big difference, bringing London down to 141 per cent of the UK average, because the large net inflow of commuters comes into the picture

- Adjusting for the mix of industries - in particular London's high proportion of jobs in banking, finance and business services - brings the figure down to 129 per cent

- Adjusting for the occupational mix - London's high proportion of white-collar jobs within each industry - brings down the figure to 119 per cent

- Finally, adjusting for hours worked (the average in London is 33.1 hours a week compared to a UK average of 31.1) points to an 'efficiency factor' of 111 per cent. 
Figure 1: Productivity (GVA) in London, 2017

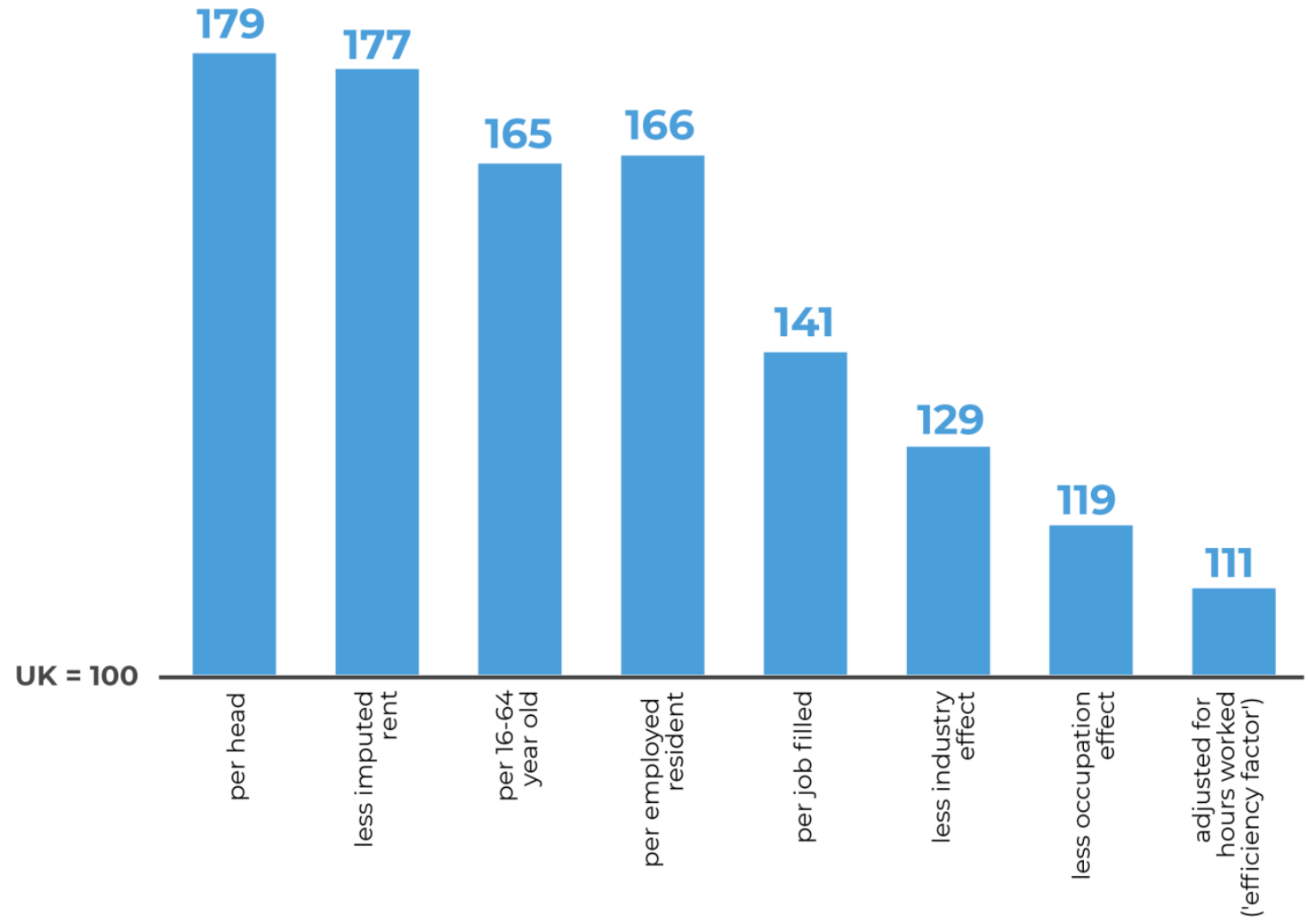

Sources: ONS and Sheffield Hallam University

In other words, despite a GVA per head almost 80 per cent higher than the national average, the efficiency with which goods and services are produced in London appears to be little more than 10 per cent above average. Furthermore, given the difficulty of making adequate adjustment for the concentration of the very most senior and highest-earning posts in London, this 'efficiency factor' is almost certainly an overestimate.

\section{Example: West Wales \& the Valleys}

West Wales \& the Valleys, a sub-region with a population of almost two million, is close to the other end of the spectrum with a GVA per head of just 63 per cent of the UK average barely a third of the level in London. Figure 2 disaggregates this low figure.

- Deducting imputed rent makes no difference - whilst owner-occupation is widespread in West Wales \& the Valleys, the impact is offset by low housing costs

- Re-basing on the working age population raises the figure to 65 per cent because West Wales \& and the Valleys has a high proportion of over-65s 
Figure 2: Productivity in West Wales \& the Valleys, 2017

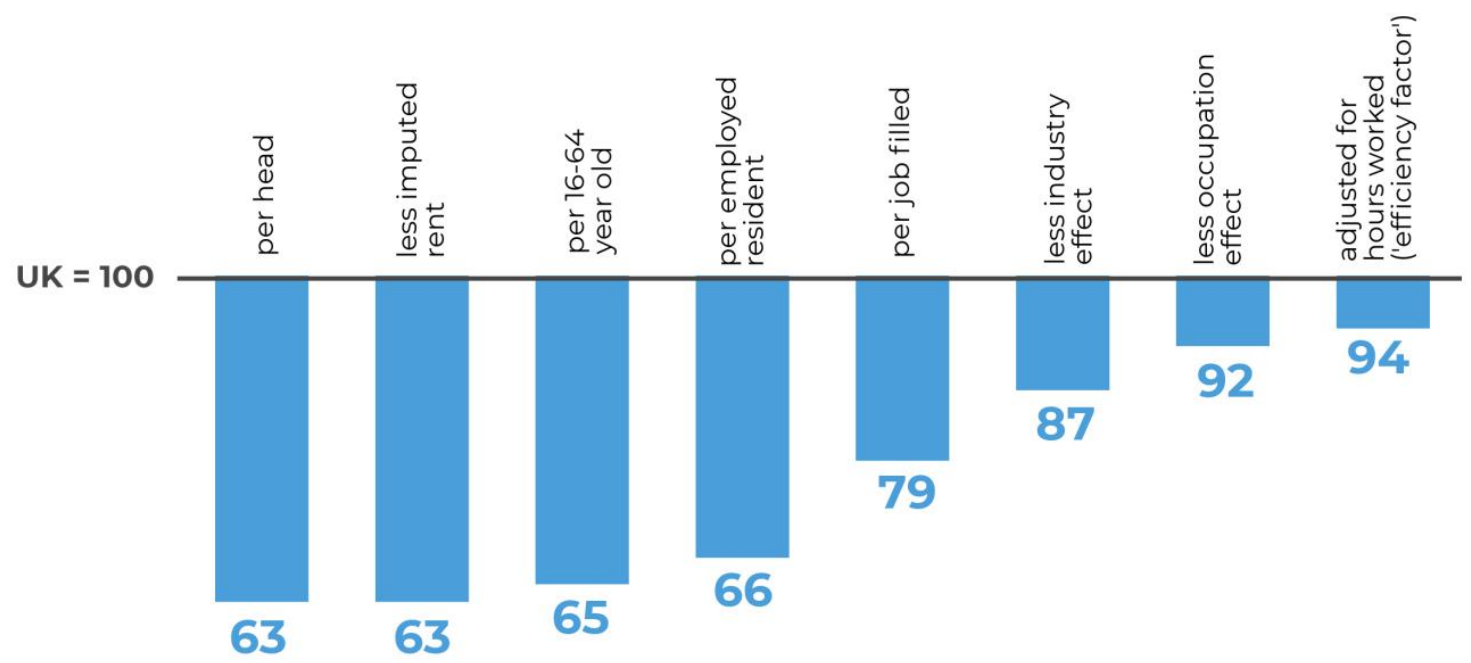

Sources: ONS and Sheffield Hallam University

- GVA per employed resident is a little higher - 68 per cent of the UK average because the area has high numbers out of paid employment, for example on disability benefits

- GVA per filled job is notably higher, at 79 per cent, because large numbers commute out of West Wales \& the Valleys, for example to Cardiff and Newport

- Adjusting for the mix of industries raises the figure further to 87 per cent of the UK average

- Adjusting for the occupational mix raises the figure even further to 92 per cent

- Finally, adjusting for hours worked points to an 'efficiency factor' of 94 per cent

In other words, despite a GVA per head only a little over 60 per cent of the UK average, the efficiency with which goods and services are produced in West Wales \& the Valleys appears to be less than 10 per cent below the national average. Also, as with London, the difficulty of making fine-grain adjustments for industry and occupational mix may mean that even this shortfall is overestimated. 
Figures 3, 4 and 5 compare all UK sub-regions on three indicators of productivity:

- GVA per head

- GVA per filled job

- 'Efficiency factor'

In each case the sub-regions are ranked from highest to lowest but the statistics are all presented on the same scale to facilitate comparisons between the indicators.

The striking feature here is the convergence between local areas in moving from one measure of productivity to another. The big differences across the country in GVA per head are lessened in looking at GVA per filled job and lessened still further in looking at 'efficiency'.

In particular, after adjusting for all the influences on productivity including industry and occupational mix, the differences in efficiency across the UK - that is, how well productive tasks are undertaken - appear modest. 38 out of 46 of sub-regions are within a narrow range of plus or minus 10 per cent of the UK average. London loses its top-spot to Eastern Scotland (which includes Edinburgh) but not by a large margin. Thames Valley Berkshire, Solent, Enterprise M3, Cheshire \& Warrington and North Eastern Scotland also emerge favourably on this measure but in all these cases an above-par 'efficiency factor' may still owe something to the difficulty of capturing the full impact of structural factors using relatively broad industrial and occupational categories.

At the other end of the spectrum, Cornwall has an 'efficiency factor' of just 76 per cent of the UK average. Unlike other sub-regions with a low GVA per head, the figures for Cornwall do not converge strongly towards the UK average when adjustments are made for commuting, industry and occupation. The extent to which Cornwall is adrift of other sub-regions (the next lowest are Dorset, The Marches and Southern Scotland at 86 per cent) suggests that Cornwall's unusually high dependence on tourism may be a complicating factor which the adjustments for industry and occupation are unable to take fully into account, or simply that some of the output in this sector goes recorded. It seems unlikely that the production of goods and services in Cornwall is really so much less efficient than elsewhere in the UK.

Sub-regions with a low GVA per head do not necessarily emerge as below average in terms of efficiency. Tees Valley is an example: its GVA per head is just 71 per cent of the UK average but the 'efficiency factor' places it at 101 per cent. In Tees Valley's case the low GVA per head owes a great deal to the extent of unemployment and economic inactivity and to the area's mix of industries and occupations. Lancashire, the North East and Swindon \& Wiltshire also have below average GVA per head but an 'efficiency factor' on a par with the national average. 
Figure 3: GVA per head, by sub-region, 2017

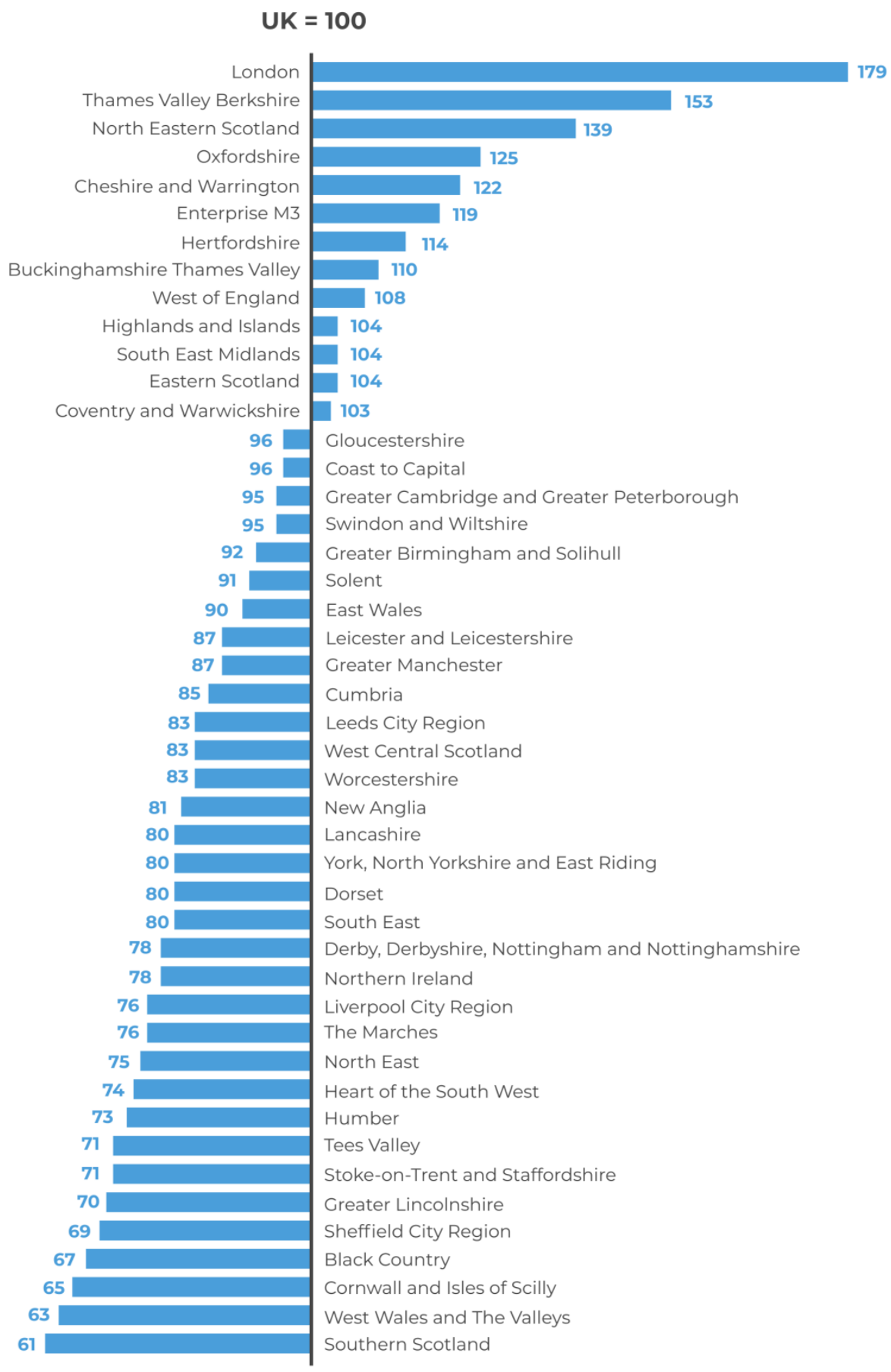


Figure 4: GVA per filled job, by sub-region, 2017

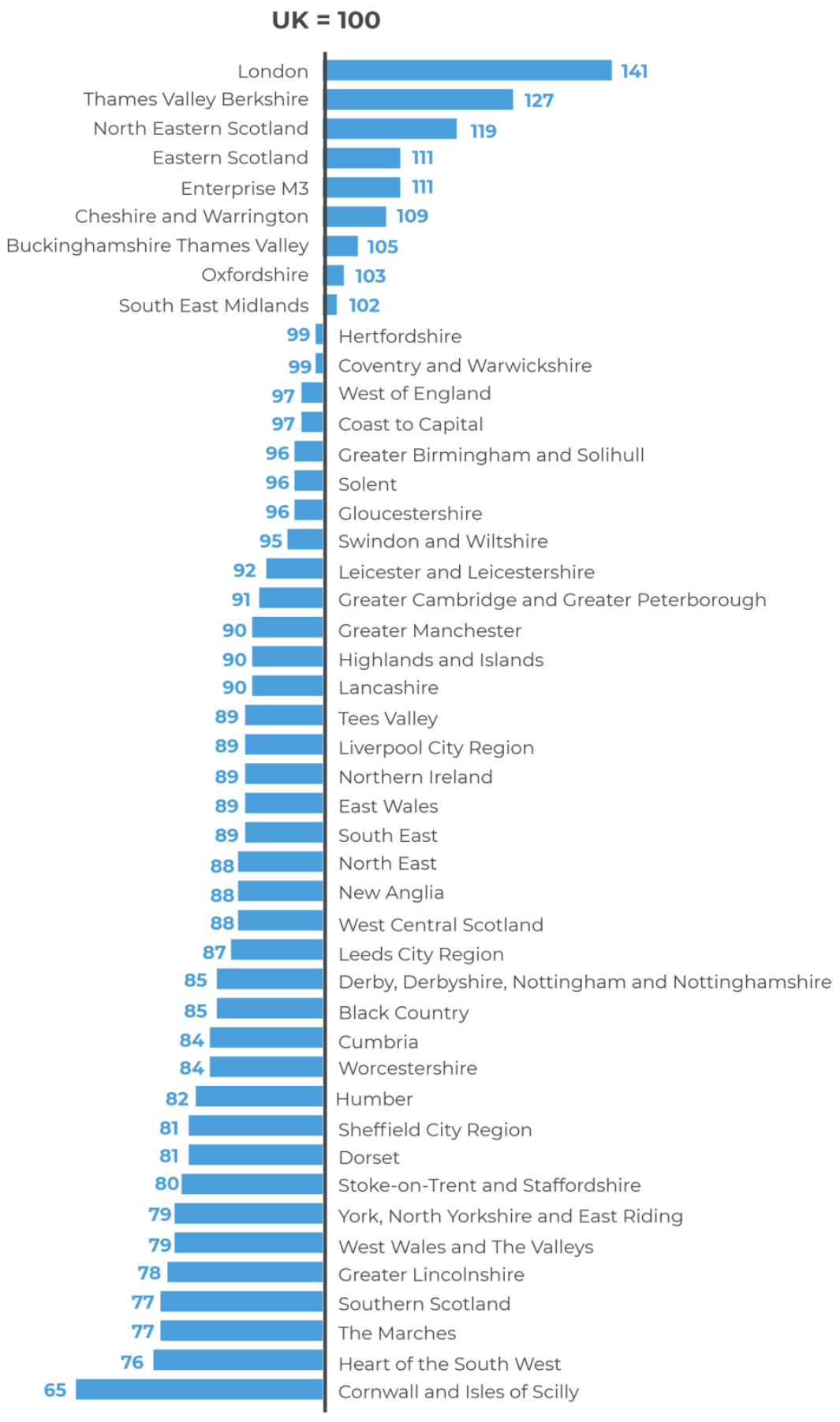


Figure 5: 'Efficiency factor', by sub-region, 2017

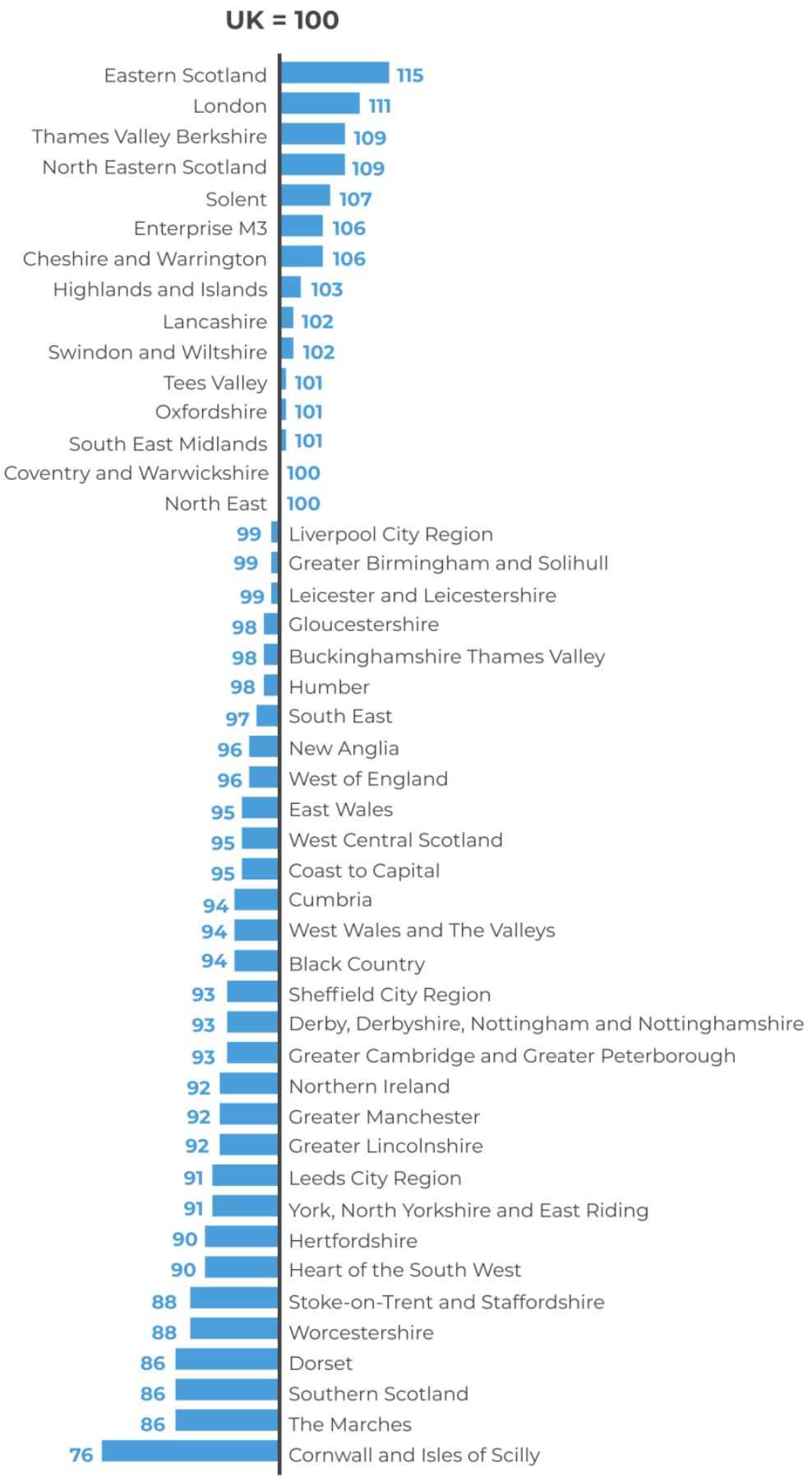

Sources: ONS and Sheffield Hallam University 


\section{The main regional cities}

Figure 6 disaggregates productivity for Britain's eleven main regional cities ${ }^{12}$. As a group, they have a GVA per head of 109 per cent of the UK average.

- Excluding imputed rent raises the GVA figure to 113 per cent of the UK average

- Re-basing on the working age population brings the cities down again, to 105 per cent, because the over-65s make up a smaller than average share of their population

- GVA per employed resident pushes the figure back up again, to 115 per cent of the UK average, because the cities have a high, economically-inactive student population and in some cases large numbers out-of-work on benefits

- GVA per filled job makes a big difference, bringing the cities down to 94 per cent of the UK average, because as in London a large net inflow of commuters comes into the picture

- Adjusting for the mix of industries and for the occupational mix makes only marginal difference

- Finally, adjusting for hours worked points to an 'efficiency factor' in the main regional cities of just 93 per cent of the UK average

Figure 6: Productivity in the main regional cities, 2017

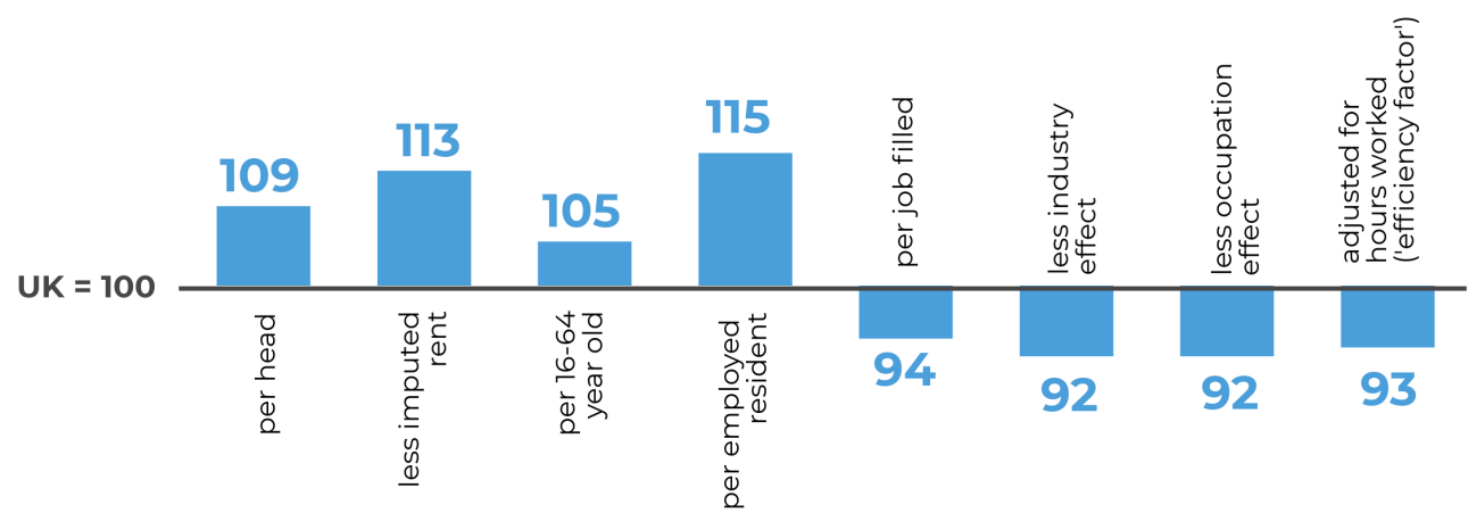

Sources: ONS and Sheffield Hallam University

\footnotetext{
${ }^{12}$ Birmingham, Bristol, Cardiff, Edinburgh, Glasgow, Leeds, Liverpool, Manchester, Newcastle upon Tyne, Nottingham, Sheffield. All defined by their local authority. The data on imputed rent for Cardiff and Newcastle is for their respective NUTS 3 regions.
} 
Figure 7: Productivity by city, 2017

\section{GVA per job}

Source: ONS

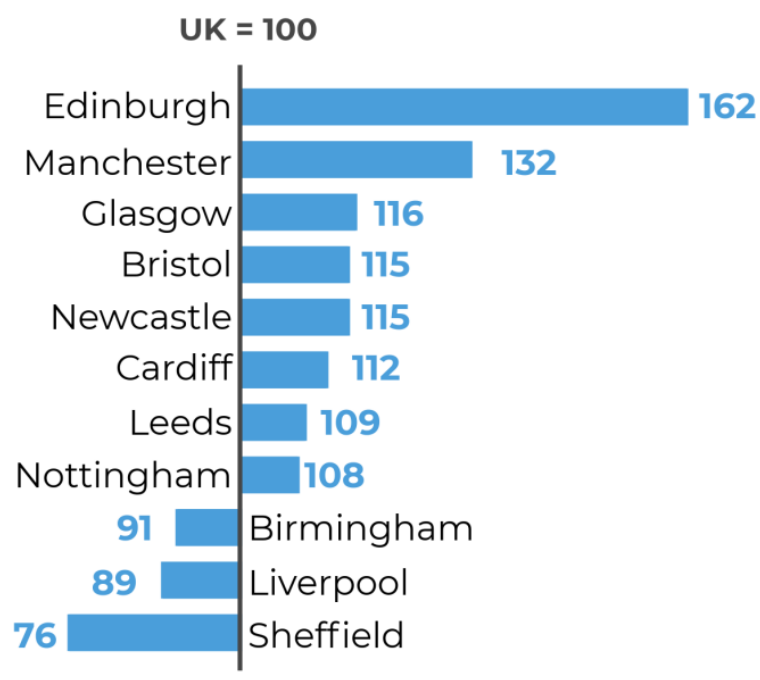

GVA per filled job

Source: ONS

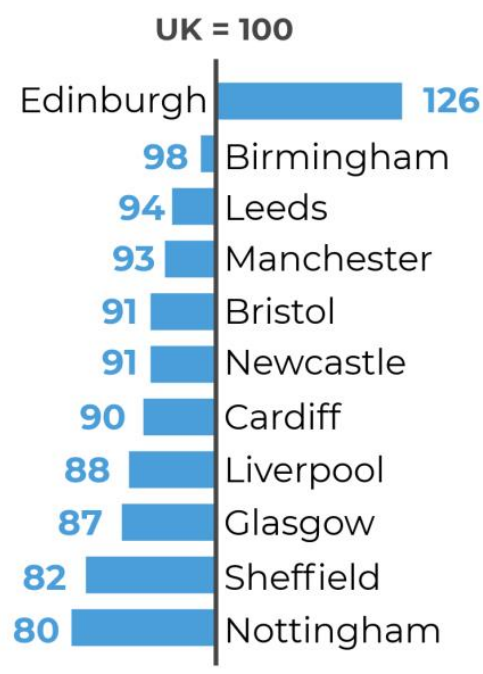

\section{'Efficiency factor'}

\begin{tabular}{|c|c|}
\hline \multicolumn{2}{|c|}{ UK = 100} \\
\hline Edinburgh & 116 \\
\hline 98 & Birmingham \\
\hline 95 & Liverpool \\
\hline 94 & Newcastle \\
\hline 94 & Glasgow \\
\hline 93 & Cardiff \\
\hline 92 & Sheffield \\
\hline 89 & Leeds \\
\hline 85 & Nottingham \\
\hline 81 & Bristol \\
\hline 81 | & Manchester \\
\hline
\end{tabular}

Sources: ONS and Sheffield Hallam University 
Overall, these figures tell a revealing story. Although the main regional cities as a group have a GVA per head that is well above the UK average, on two other key measures of productivity - GVA per filled job (an established ONS measure) and the estimated 'efficiency factor' - they are actually some way below the national average.

Figure 7 presents the figures for each city for GVA per head, for GVA per filled job and for the 'efficiency factor', revealing substantial diversity.

Sheffield, for example, has a GVA per head of only 76 per cent of the UK average but the figure rises to 82 per cent per filled job and, after adjusting for industry, occupation and hours worked, to 92 per cent of the UK average.

Edinburgh moves in the opposite direction, from 162 per cent on GVA per head to 126 per cent per job filled and to 116 per cent on the 'efficiency factor'. Edinburgh remains the only one of the main regional cities with an 'efficiency factor' above the UK average but, as with London, it is possible that the adjustment for occupational mix has failed to take full account of Edinburgh's concentration of high-end jobs in finance, law and government.

\section{Implications of the findings}

\section{For agglomeration economics}

At first sight, the productivity figures here present a serious challenge to agglomeration economics. What they say is that although output per head in the cities, and especially in London, is well above the national average, once adjustments have been made for structural and labour market factors there is little or no evidence that the cities are any more efficient at what they do than most other locations across Britain. Even London's impressive lead in GVA per head falls away to the extent that its productivity measured in terms of efficiency is only a little above the UK average and even some of this remaining advantage may be a statistical illusion.

Agglomeration economics, which has so dominated thinking on cities and regions in recent times, postulates that firms are more efficient if they are clustered together and that cities are therefore better locations for much economic activity. The evidence here on efficiency, from across the UK, does not support this view.

In fact, what is striking is how little efficiency seems to vary across the UK. There are big differences between places in output per head but once allowances are made for commuting patterns, industry, occupational mix and so forth the underlying variation in the efficiency with which goods and services are produced is really quite modest. By implication, workers do not seem to be any harder-working in some parts of the country than in others, nor are their employers better at organising production in some places than others. 
This is a startling conclusion given the big differences in GVA per head across the UK but it does not mean that agglomeration economics is entirely redundant. What remains clear is that the cities have major concentrations of jobs that draw in commuters from surrounding areas and further afield, and that in London in particular there is a concentration of highproductivity industries and high-productivity occupations. This has not happened by accident. In practice, some businesses need to be close to other businesses or to be in central locations where they have access to a large labour market or a large customer base and for these firms a city is a sensible location. This is agglomeration economics at work.

There are also likely to be specific sectors, hidden within the aggregate figures, in which businesses are for a range of possible reasons likely to be more efficient if they are located in a city. Equally, however, there are also likely to be other sectors for which a city would be distinctly inefficient location - activities requiring very large sites or ready access to the motorway network, such as national distribution depots, are an example.

What we can say however, on the basis of the evidence here, is that in so far as agglomeration economies do operate it is not on the whole because the activities in cities are carried out so much more efficiently than elsewhere.

\section{Implications for public policy}

There has always been a tension in urban and regional policymaking between efficiency and equity. If the goal is to maximise economic growth - efficiency - there is a case for allowing business activity to gravitate to the places where it operates best and even for reinforcing growth in higher-performing places by public investment. If the goal is fairness to individuals and communities - equity - what is needed are policies that divert growth and jobs to less prosperous places.

In recent years in the UK the emphasis has been more on efficiency than equity. Regional economic policy since 2010, and certainly since 2015 when England's Regional Growth Fund came to an end, is probably now weaker than at any time for more than fifty years. There is a wariness of encouraging businesses to locate in less prosperous parts of the country, a fear indeed that to be too far from London or one of the big regional cities is to opt for backwardness and inefficiency.

The evidence here does not support the view that large parts of Britain, especially the places with low GVA per head, are somehow inefficient locations. Actually, taking their economies as a whole, most places across the UK appear to share national standards of efficiency in the goods and services they produce.

This should be a 'green light' for regional economic policy because it indicates that there is no obvious conflict between efficiency and equity. Supporting growth in North East England for example, or in South Wales or Merseyside, should not therefore mean that the UK economy as a whole will be any smaller because the evidence does not point to business in these places being carried out any less efficiently than elsewhere. Indeed, if underutilised resources are brought into use the economy as a whole would be larger. 
Of course, not all businesses can expect to prosper in all locations. A merchant bank might not expect to flourish in Cumbria or a national distribution depot in the Highlands \& Islands, but these are commercial judgements that all businesses can be expected to make. What government should have confidence in doing is in supporting growth and jobs in the parts of the UK that need them most by improving infrastructure and by supporting investment in business premises, plant \& machinery, R\&D and skills.

The evidence here is that the UK's less prosperous areas are not inherently inefficient or unsuitable locations for business activity. 


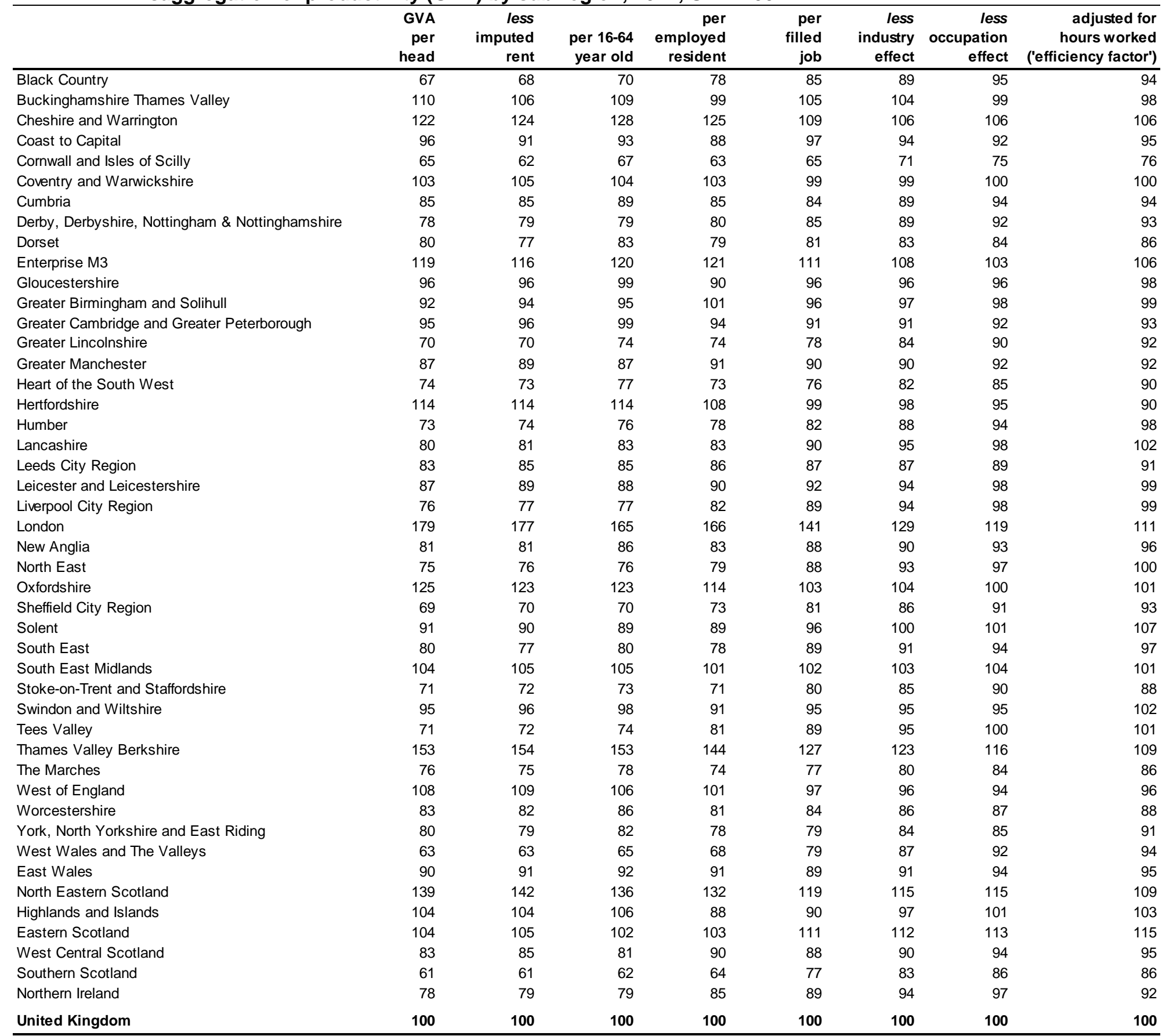

Sources: ONS and Sheffield Hallam University 
Disaggregation of productivity (GVA), main regional cities, 2017, UK =100

\begin{tabular}{|c|c|c|c|c|c|c|c|c|}
\hline & $\begin{array}{r}\text { GVA } \\
\text { per } \\
\text { head }\end{array}$ & $\begin{array}{r}\text { less } \\
\text { imputed } \\
\text { rent }\end{array}$ & $\begin{array}{r}\text { per } 16-64 \\
\text { year old }\end{array}$ & $\begin{array}{r}\text { per } \\
\text { employed } \\
\text { resident }\end{array}$ & $\begin{array}{r}\text { per } \\
\text { filled } \\
\text { job }\end{array}$ & $\begin{array}{r}\text { less } \\
\text { industry } \\
\text { effect }\end{array}$ & $\begin{array}{r}\text { less } \\
\text { occupation } \\
\text { effect }\end{array}$ & $\begin{array}{r}\text { adjusted for } \\
\text { hours worked } \\
\text { ('efficiency factor') }\end{array}$ \\
\hline Leeds & 109 & 112 & 108 & 107 & 94 & 90 & 88 & 89 \\
\hline Sheffield & 76 & 78 & 75 & 81 & 82 & 87 & 89 & 92 \\
\hline Nottingham & 108 & 113 & 102 & 129 & 80 & 84 & 85 & 85 \\
\hline Newcastle upon Tyne & 115 & 118 & 109 & 122 & 91 & 93 & 92 & 94 \\
\hline Liverpool & 89 & 93 & 85 & 97 & 88 & 93 & 95 & 95 \\
\hline Manchester & 132 & 139 & 124 & 141 & 93 & 86 & 83 & 81 \\
\hline City of Edinburgh & 162 & 165 & 149 & 152 & 126 & 117 & 113 & 116 \\
\hline Glasgow City & 116 & 120 & 107 & 125 & 87 & 86 & 93 & 94 \\
\hline Cardiff & 112 & 114 & 106 & 113 & 90 & 90 & 90 & 93 \\
\hline Birmingham & 91 & 94 & 92 & 109 & 98 & 98 & 98 & 98 \\
\hline Bristol & 115 & 118 & 108 & 106 & 91 & 86 & 82 & 81 \\
\hline Total regional cities & 109 & 113 & 105 & 115 & 94 & 92 & 92 & 93 \\
\hline
\end{tabular}

Sources: ONS and Sheffield Hallam University 



\section{CRESR \\ Sheffield Hallam University \\ City Campus \\ Sheffield S1 1WB \\ +44(0)1142253073 \\ e: cresr@shu.ac.uk \\ w: shu.ac.uk/cresr}

ISBN: 978-1-84387-427-0

DOI: $10.7190 /$ cresr.2019.5555633394

\section{Sheffield Centre for \\ Hallam Regional Economic University and Social Research}




\section{Sheffield Hallam University}

Local productivity: The real differences across UK cities and regions

BEATTY, Christina <http://orcid.org/0000-0003-0943-9979> and FOTHERGILL, Stephen $<$ http://orcid.org/0000-0002-4201-0640>

Available from the Sheffield Hallam University Research Archive (SHURA) at:

http://shura.shu.ac.uk/24893/

\section{Copyright and re-use policy}

Please visit http://shura.shu.ac.uk/24893/ and http://shura.shu.ac.uk/information.html for further details about copyright and re-use permissions. 